\title{
Penerapan Aliran Filsafat Empirisme dalam Manajemen Pembelajaran guna meningkatkan Kompetensi Guru di MAS Al Barakah
}

\author{
Deni Rahmat Jatnika \\ Universitas Negri Islam Sunan Gunung Djati, Bandung \\ denirahmat04@gmail.com
}

\begin{abstract}
Abstrak
Penulisan artikel ini bertujuan mengungkap tata kelola pendidikan berdasarkan perspektif filsafat empirisme eksperimental yang dipelopori oleh Thomas Hobes di MAS Al-Barakah, menurut aliran empirisme, pendidikan itu berdasarkan pengalaman, karena semakin banyak pengalaman maka akan semakin banyak pula pengetahuan. Dengan kata lain menitik beratkan bahwa kebenaran atau pengetahuan itu ialah ketika sebuah materi atau konsep dapat diperoleh berdasarkan pengalaman dengan memperhatikan kegunaannya secara praktis. Pendekatan kajian yang digunakan dalam artikel ini adalah studi literatur dan observasi kajian filsafat empirisme eksperimental, mengumpulkan beberapa pustaka, data, dan berita yang ada yang kemudian di analisis sehingga didapatkan intisarinya. Hasil pembahasan dalam artikel ini menjelaskan bahwa kompetensi guru di lembaga pendidikan MAS Al-Barakah mengalami kemajuan dibidang pembelajaran ilmu tidak hanya materi belajar di kelas saja tetapi pengalaman pun mengarahkan guru untuk menerapkan metode pembelajaran yang didapat dengan konsep yang praktis dan kreatif, dengan ilmu praktik dan pengalaman ini akan bermanfaat ketika guru mengajar di kelas maupun diluar kelas.
\end{abstract}

Kata kunci : Filsafat Empirisme; Manajemen Pembelajaran; Kompetensi Guru.

\begin{abstract}
Writing this article aims to expose the governance of education based on the perspective of the experimental empirical philosophy spearheaded by Thomas hobes in MAS Al-Barakah, according to the emphatism, the education was based on experience, as more experience would result in more knowledge. In other words the implication is that truth or knowledge is when a material or concept can be acquired from experience by observing its practical use. The approach to studies used in this article is the study of the literature and observation of experimental empirical philosophy, collecting some existing libraries, data, and news that were later analyzed and thus obtained its essence. The results of the discussion in this article explain that teacher competence at the MAS Al-Barakah education institute is progressing in the field of study of science not only only the learning materials in the classroom but the experience also directed teachers to apply the learning methods acquired with practical and creative concepts, with practice and this experience will be helpful when teachers teach class as well as outside the class.
\end{abstract}

Keywords: Emphatically philosophy; Learning management; Teacher competenc. 


\section{Pendahuluan}

Aliran empirisme mendapat respon di negara indonesia, termasuk dunia pendidikan juga merasakan efek dari aliran ini. Seseorang yang beraliran empirisme biasanya berpendirian bahwa pengetahuan didapat melalui penampungan yang secara pasif menerima hasil-hasil penginderaan tersebut. Empiris memegang peranan yang amat penting bagi pengetahuan, bahkan merupakan satu-satunya sumber dan dasar ilmu pengetahuan menurut penganut empirisme. Pengalaman inderawi sering dianggap sering dianggap sebagai pengadilan yang tertinggi

Penelitian ini didasari oleh jurnal yang dikeluakan oleh jurnal Edueksos Volume I No I Bulan juni 2012 yang mengangkat Judul "Kontribusi Empirisme Terhadap Pendidikan Ilmu Pengetahuan Sosial” yang ditulis oleh Ratna Puspitasari(Puspitasari n.d.). Penelitian ini membuahkan hasil bahwa pegetahuan Pengenalan manusia terhadap seluruh pengalaman yang dilaluinya ( mencium, merasa, mengecap, mendengar ) menjadi dasar bagi hadirnya gagasan-gagasan sederhana. Namun pikiran bukanlah sesuatu yang pasif terhadap segala sesuatu yang datang dari luar. Beberapa aktivitas berlangsung dalam pikiran. Gagasan-gagasan yang dating dari indera diolah dengan cara berfikir, bernalar, mempercayai, meragukan dan dengan demikian memunculkan apa yang disebut perenungan. Empirisme timbul sebagai reaksi dari paham rasionalisme "Rene Descartes"dan membawa kontribusi dalam Pendidikan Ilmu Pengetahuan Sosial.

Peserta didik bukanlah sehelai kertas putih yang menunggu untuk ditulisi, atau replika orang dewasa dalam format kecil yang dapat dimanipulasi sebagai tenaga buruh yangmurah, melainkan, anak adalah entitas yang unik, yang memiliki berbagai potensiyang masih latent dan memerlukan proses serta sentuhan-sentuhan tertentu dalamperkembangannya. Mereka yang memulai dari egosentrisme dirinya kemudian belajar,akan menjadi berkembang dengan kesadaran akan ruang dan waktu yang semakin luas, dan mencoba serta berusaha melakukan aktivitas yang berbentuk intervensi dalam dunianya. Maka dari itu, pendidikan IPS adalah salah satu upaya yang akan membawa kesadaran terhadap ruang, waktu, dan lingkungan sekitar bagi anak

Pendidikan merupakan salah satu petunjuk perubahan sosial yaitu perubahan ke arah yang lebih baik, tidak mungkin terlepas dari peran agen perubahan yaitu manusia yang berkualitas yang memiliki keterampilan dan daya saing tinggi, mampu berkompetisi dalam persaingan di zaman modern dan globalisasi. Untuk mewujudkan cita-cita atau impian tersebut, makapendidikan menjadi garda terdepan untuk menumbuh kembangkan seluruh potensi peserta didik baik potensi jasmani maupun potensi rohani dalam rangkan untuk mencetak atau melahirkan manusia-manusia yang insan kamil yang beriman kepada Allah SWT, memiliki kecerdasan dan berwawasan luas, bertanggung jawab, serta berakhlakul karimah. Dengan demikian lembaga pendidikan sebagai lembaga penyelengara Pendidikan dan pengajaran harus senantiasa selalu 
berbenah diri secara terus menerus dan berkesinambungan ke arah pengembangan sesuai dengan kebutuhan peserta didik yang selalu bertambah dan berubah-ubah setiap saat sesuai dengan kebutuhan dan tuntutan zaman yang berbeda dari waktu ke waktu. Dan yang menentukan keberhasilan pelaksanaan pendidikan dalam suatu lembaga pendidikan adalah manakala proses pembelajaran dapat berjalan dengan baik dan begitu pula kegiatan pembelajaran dapat berhasil atau berkualitas manakala manajemennya dikelola dengan baik. Untuk itu yang menentukan manajemen dapat berjalan dan terlaksana dengan baik sangat ditentukan oleh tersedianya tenaga-tenaga siap pakai yang professional trampil dan handal.

Hal ini semakin dituntut tersedianya sumber daya yang handal siap pakai khususnya untuk melaksanakan manajemen pembelajaran dalam rangka untuk meningkatkan kualitas lembaga pendidikan utamanya kualitas output dalam hal ini yang dimaksudkan adalah outfut peserta didik. Terkait dengan hal tersebut, tentunya kualitas guru yang baik merupakan modal yang sangat diharapkan untuk sebuah pelayanan yang baik dan akan menentukan mutu lulusan dari sebuah lembaga pendidikan. Maka untuk menghasilkan lulusan yang berkualitas, Madrasah Aliayah Swasta Al-Barakah memerlukan guru yang bermutu/berkualitas sebagai pelaku dan penentu utama dalam kegiatan pembelajaran.

Akan tetapi sebagaimana kenyataannya yang disaksikan selama ini dimana masih ada guru yang kurang memiliki kesadaran dalam Menyusun silabus dan Rencana Pelaksanaan Pembelajaran (RPP) untuk dijadikan sebagai acuan atau pedoman dalam melaksanakan kegiatan pembelajaran di kelas. Bahkan ada yang tidak menyusun atau membuatnya, ada juga membuat dan menyetor silabus dan RPP di sekolah akan tetapi dengan tujuan untuk persiapan manakala ada tim pemerikasa/pengawas ke sekolah dan atau untuk keperluan lainnya. Padahal sesungguhnya rencana pelaksanaan pembelajaran yang disusun dengan baik untuk dijadikan pedoman dalam melaksanakan pembelajaran maka proses pembelajaran menjadi lebih sistematis dan terarah dan merupakan faktor penentu keberhasilan kegiatan pembelajaran. Sehubungan dengan uraian di atas, Madrasah Aliyah Swasta (MAS) Al-Barakah kecamatan Pasirwangi kabupaten Garut termasuk di dalamnya berdasarkan dari hasil wawancara awal dengan salah seorang guru MAS Al-Barakah.

Berkaitan dengan hal ini, menandakan bahwa penerapan manajemen pembelajaran di Madrasah Aliyah Swasta Al-Barakah belum terlaksana dengan baik. Berkaitan dengan permasalahan tersebut, menjadi pembahasan dalam penelitian ini yaitu bagaimana proses penerapan atau pelaksanaan empirisme dalam manajemen pembelajaran untuk meningkatkan kompetensi guru di MAS Al-Barakah? bagaimana bentuk-bentuk peningkatan guru MAS Al-Barakah? Apa faktor pendukung maupun penghambat pelaksanaan manajemen pembelajaran dalam meningkatkan kompetensi guru di Madrasah Aliyah Swasta Al-Barakah?. 
Penelitian ini bertujuan untuk mendeskripsikan tentang manajemen pembelajaran, dan bentuk-bentuk peningkatan kompetensi guru, serta factor pendukung maupun faktor penghambat pelaksanaan manajemen pembelajaran dalam meningkatkan kompetensi guru di MAS Al-Barakah berlandaskan pada teori empirisme, sehingga guru dapat belajar dari pengalaman-pengalaman selama proses belajar mengajar sehingga dapat meningkatkan kompetensinya dalam hal penyampaian materi maupun evaluasi pembelajaran

\section{Metode Penelitian}

Dalam penulisan ini secara umum penulis menggunakan pendekatan kajian deskriptif dan observatif kajian filsafat empirisme. Secara garis besar untuk memperoleh data yang diperlukan dalam penulisan ini, penulis menggunakan teknik pengumpulan data berupa buku, dokumen, hasil wawancara dan lain-lain. Data yang diperoleh dianalisis, dan disimpulkan sehingga mendapatkan kesimpulan mengenai studi literatur.

\section{HaSil DAN PEMBahasan}

\section{A. Temuan penelitian}

\section{Perencanaan Pembelajaran}

Berkaitan dengan perencanaan pembelajaran dalam rangka persiapan dalam proses kegiatan pembelajaran, seorang guru harus mempersiapkan segala sesuatunya yang terkait di dalamnya mencakup penyusunan program pengajaran. Dalam hal ini peneliti berdasarkan hasil observasi dan wawancara dengan beberapa informan, perencanaan pembelajaran yang dilaksanakan oleh guru-guru MAS Al-Barakah adalah sebagai berikut:

\section{a. Silabus}

Istilah silabus dapat didefenisikan sebagai "garis besar, ringkasan,ikhtiar, atau pokok-pokok isi atau materi pelajaran".(Abdul Majid 2008) Di MAS Al-Barakah silabus ada disusun oleh seorang guru secara sendiri adapula silabus yang disusun oleh guru secara tim teaching. Adapun silabus yang disusun secara individu adalah silabus mata pelajaran untuk mata pelajaran diluar mata pelajaran keagamaan untuk kelas sepuluh, sebelas, dan dua belas. Sedangkan silabus mata pelajaran untuk matapelajaran keagamaan untuk setiap kelas disusun atau dibuat oleh guru secara tim.

b. Rencana Pembelajaran (RP)

Rencana pembelajaran adalah "perangkat perencanaan pembelajaran yang dijadikan pedoman dalam melaksanakan proses pembelajaran untuk mencapai satu 


\section{Rahmat \& Irawan}

kompetensi".(Suwardi 2007) Rencana pembelajaran atau biasa dikenal di lembaga sekolah dengan istilah RPP adalah sangat penting dalam mempersiapkan pembelajaran untuk hari esok. Rencana pembelajaran ini memuat tentang kompetensi dasar, indikator pencapaian, materi, media/alat, alokasi waktu, dan metode yang digunakan Di MAS AlBarakah dalam pembuatan RPP berdasarkan hasil wawancara dengan informan mengatakan bahwa pada umumnya guru telah membuatnya akan tetapi tidak semua guru menyusun untuk dijadikan pedoman pada setiap pertemuan di kelas, tetapi ada sebagian guru membuat RPP untuk keperluan administrasi.

\section{b. Rencana Pengelolaan Kelas}

Menyangkut perencanaan pengelolaan kelas dalam rangka untuk mengatur dan membenahi semua perlengkapan kelas dalam proses pembelajaran seperti tempat duduk siswa dipisah menurut jenis kelaminnya. Namun dengan sendirinya siswa mengambil tempat duduk secara terpisah dimana siswa perempuan duduk sama perempuan dan siswa laki-laki duduk sama laki-laki, serta pembentukan tempat duduk untuk kerja kelompok dalam kelas belum ada dalam perencanaan pembelajaran. Dalam hal ini guru tidak merencanakan pengeloalaan kelas secara tertulis dan terstruktur, akan tetapi mengikuti pengelolaan kelas sebagaimana yang sudah diberlakukan di MAS Al-Barakah. Namun ada satu dua orang guru sewaktu-waktu mengatur posisi tempat duduk menyesuaikan dengan metode yang digunakan dalam menyampaikan materi.

\section{Pengorganisasian Pembelajaran}

Dalam melakukan pengorganisasian pembelajaran di MAS Al-Barakah dilakukan sebelum masuk mengajar dan ketika masuk mengajar. Yaitu guru mengawali dengan mempersiapkan segala sesuatunya sebelum masuk mengajar antara lain guru mempersiapkan dan merumuskan hal-hal pokok yang harus diberikan kepada siswa, menyiapkan alat atau media yang akan digunakan, dan menentukan waktu berdasarkan materi yang akan diajarkan. Sedangkan ketika mengajar di kelas guru tetap mengamati semua siswa berdasarkan karakter dan kemampuannya masing-masing dan melakukan penilaian kepada siswa terhadap hasil belajar yang diperolehnya.

Berdasarkan temuan peneliti di lapangan bahwa proses pengorganisasian pembelajaran yang dilakukan dalam kelas adalah rata-rata atau pada umumnya guru menggunakan pengorganisasian kelas model tradisional dan sebahagian kecil guru sewaktu-waktu memvariasikan dengan model lain seperti model $U$ atau melingkar dan sebagainya. Di samping itu untuk mengurangi kebosanan siswa dalam menerima materi pelajaran, alangkah baiknya pengorganisasian kelas menggunakan format atau model yang berpariatif. 


\section{Pelaksanaan Pembelajaran}

Berdasarkan wawancara dengan informan, pelaksanaan pembelajaran di MAS AlBarakah dilaksanakan selama enam hari dalam setiap minggunya. Adapun jadual pelajaran yaitu pada hari Senin, hari Selasa, hari Rabu, hari Kamis, hari jum'at dan hari Sabtu.

a. Memulai pembelajaran

Berdasarkan pengamatan peneliti mengawali pembelajaran sebagaimana yang dilakukan guru di MAS Al-Barakah terlebih dahulu mengawali dengan kata-kata atau ucapan salam kepada seluruh siswa yang ada di kelas yang diucapkan ketika masuk di kelas. Kemudian dilanjutkan guru mengabsen siswa sambil mencari informasi tentang ketidakhadiran siswa atau yang terlambat disaat itu. Selanjutnya guru melakukan apersepsi apakah siswa masih mengingat dan memahami materi yang telah dipelajari sebelumnya. Lalu guru melakukan pre tes sebagai tes awal dengan memberikan beberapa pertanyaan yang berkaitan dengan materi yang akan diajarkan. Namun tidak semua guru melakukan sebagaimana halnya di atas, akan tetapi ada juga guru langsung membahas materi baru tanpa menanyakan materi yang sudah dibahas sebelumnya.

b. Penyampaian materi pembelajaran

Sebagaimana wawancara dengan beberapa informan, sebelum guru memulai materi baru, terlebih dahulu menyampaikan tema pokok bahasan yang akan dibahas kemudian menyampaikan materi kepada siswa agar mudah dipahami dan dicerna. Oleh karena itu penyampaian materi pembelajaran perlu adanya perencanaan yang matang yang disesuaikan dengan tingkat kematangan siswa, karena sesungguhnya kemampuan siswa dalam menerima materi pelajaran adalah berbeda-beda, jadi penyampaian dan penjelasan materi pembelajaran yang disesuaikan dengan kondisi dan karakter setiap siswa adalah bagian penting dari proses pembelajaran.

c. Penggunaan alat pembelajaran

Berdasarkan wawancara dengan informan bahwa, di MAS Al-Barakah, guru dalam menjelaskan materi pembelajaran alat yang umum digunakan hingga sekarang adalah white board dan alat tulisnya (spidol) ini sulit untuk ditinggalkan oleh para guru ketika mengajar di kelas. Sebenarnya alat pembelajaran yang sudah tersedia di MAS ini bukan hanya white board satu- satunya akan tetapi ada alat pembelajaran lainnya namun guru tidak menggunakannya secara maksimal. Diantaranya LCD proyektor, laptop, tape record, dan lain-lain, namun alat tersebut kurang digunakan guru ketika mengajar karena di samping faktor ketidaklengkapannya fasilitas yang tersedia di dalam kelas yaitu belum semua kelas tersedia LCD proyektor yaitu baru tiga (3) ruangan yang ada yakni ruangan 


\section{Rahmat \& Irawan}

kelas X A, kelas XI A, dan kelas XII A. Di samping itu sebagian guru masih terbatas dalam penguasaan alat teknologi pembelajaran.

\section{d. Penggunaan Metode Pembelajaran}

Dalam proses pembelajaran seorang guru perlu menggunakan metode yang tepat dalam menyampaikan materi agar peserta didik dapat memahami informasi atau pesan dengan baik karena penyampaian materi pelajaran dengan menggunakan metode yang tepat akan berbeda hasilnya dengan penyampaian materi dengan menggnakan metode yang kurang tepat atau tidak sesuai dengan materi pelajaran yang diajarkan. Menurut Ahmad Tafsir dalam Ramayulis Metode mengajar adalah "cara yang paling tepat dan cepat dalam mengajarkan mata pelajaran".(Rasmi 2010) Adapun metode yang sering dipergunakan guru dalam menyampaikan materi pembelajaran di MAS Al-Barakah adalah antara lain menggunakan metode ceramah, metode tanya jawab, metode demonstrasi. Berdasarkan pengamatan peneliti, metode yang paling banyak digunakan guru dalam menyampaikan materi pembelajaran adalah gabungan dua metode antara ceramah dan tanya jawab. Hal ini dapat menunjukkan bahwa metode ini dapat meningkatkan pemahaman terhadap materi yang disajikan oleh guru dengan melalui metode ini.

e. Mengakhiri pembelajaran

Dalam mengakhiri pembelajaran atau kegiatan penutup, kegiatan penting yang harus dilaksanakan oleh guru adalah membuat rangkuman dan bahan-bahan yang baru dijelaskan, terhadap materi pembelajaran yang telah disampaikan dan memberikan tindak lanjut yang harus dipelajari peserta didik dan merupakan evaluasi bagi pembelajaran. guru setelah selesai menjelaskan materi pembelajaran lalu memberikan post tes yang merupakan tahap akhir pelaksanaan pembelajaran. Pada tahap ini guru menyimpulkan dari materi-materi yang telah diajarkan dan dipelajari oleh siswa, selain itu dengan melakukan post tes digunakan untuk mengetahui efektifitas strategi pembelajaran terutama dalam melihat keberhasilan pembelajaran dan pembentukan kompetensi khususnya untuk materi yang baru saja disampaikan. Namun menurut beberapa informan mengatakan bahwa tidak semua guru diakhir pembelajaran menyimpulkan materi dan memberikan post tes tetapi langsung saja mengakhiri pembelajaran.

\section{Evaluasi Pembelajaran}

Aspek penting dalam pengelolaan pembelajaran adalah evaluasi atau penilaian. Menurut Brinkerhoff sebagaimana yang dipahami oleh Eko Putro Widoyoko bahwa evaluasi adalah "merupakan proses yang menentukan sejauhmana tujuan pendidikan dapat dicapai".(Widoyoko 2009) Oleh karena itu guru harus memahami dan menguasai teknik 
evaluasi pembelajaran, karena untuk mengetahui sejauhmana pembelajaran atau kompetensi yang diharapkan tercapai. Menurut informan bahwa evaluasi pembelajaran yang dilaksanakan oleh guru di MAS Al-Barakah dilakukan secara lisan maupun secara tertulis. Evaluasi yang berbentuk tulisan misalnya memberikan tugastugas untuk dikerjakan siswa baik dalam bentuk tugas kelompok maupun dalam bentuk tugas mandiri. Dan tidak terkecuali penilaian perilaku atau akhlak keseharian siswa baik perilaku hubungan siswa dengan guru, hubungan siswa dengan pegawai administrasi (TU) maupun hubungan siswa dengan siswa. Namun penilaian perilaku belum maksimal dilakukan guru- guru di MAS Al-Barakah .

\section{Macam-Macam Peningkatan Kompetensi Guru di MAS Al-Barakah}

Berbicara tentang peningkatan kemampuan atau kompetensi seorang guru di lembaga pendidikan adalah tidak terlepas dari tugas dan tanggung jawab pimpinan lembaga sebagai seorang pemimpin di samping itu para guru ditekankan senantiasa selalu berusaha melaksanakan pengembangan diri dalam hal ini meningkatkan tugas keprofesionalannya yang telah diembannya. Adapun bentuk-bentuk peningkatan kompetensi guru di MAS Al-Barakah berdasarkan hasil wawancara dengan beberapa informan adalah KKG (Kelompok Kerja Guru), workshop, kegiatan seminar, dan kegiatankegiatan lainnya yang ada hubungannya dengan peningkatan dan pengembangan tugas keguruan. Untuk lebih jelasnya dapat diuraikan sebagai berikut:

\section{Kelompok Kerja Guru (KKG)}

Salah satu usaha yang dapat dilaksanakan dalam rangka untuk meningkatkan kemampuan yang profesional dalam rangka untuk mewujudkan kegiatan pembelajaran di lembaga pendidikan, maka salah satu kegiatan yang dilakukan adalah mengadakan Kelompok Kerja Guru (KKG). Adapun uraian pembahasan yang dilaksanakan dalam kegiatan KKG tersebut antara lain meliputi pembahasan menganai kurikulum, metode pembelajaran, teknik dan atau strategi pembelajaran, evaluasi, dan sebagainya. Kegiatan kelompok kerja guru tersebut merupakan kegiatan rutin yang diadakan di sekolahsekolah atau madrasah dan lazimnya diadakan setiap akhir semester yang dijadikan sebagai ajang pertemuan guru-guru untuk saling berinteraksi dan berkomunikasi diantara sesame guru dengan tujuan berbagi pengalaman menyangkut tentang pengembangan pelaksanaan pendidikan dan pengajaran yang digelutinya.

Berdasarkan hasil wawancara dengan dua orang informan merekaa mengatakan bahwa: Kegiatan kelompok kerja guru rutin dilaksanakan untuk guru Madrasah Aliyah yaitu seluruh Madrasah Aliyah Negeri se-Kabupaten Garut yang diadakan setiap selesai semester. Dimana Madrasa Aliyah sekabupaten Garut sebagai induk penyelenggara kegiatan KKG tersebut. Adapun tujuan kami menyelenggarakan kelompok kerja guru ini 


\section{Rahmat \& Irawan}

adalah dalam rangka untuk meningkatkan kompetensi kami selaku guru sehingga dalam melaksanakan kegiatan pembelajaran dapat lebih berkualitas. Ditambahkan pula pernyataan oleh salah seorang informan lainnya bahwa: Kegiatan Kelompok kerja guru ada dua yaitu ada Kelompok kera guru induk dan Kelompok kerja intern. Dimana Kelmpok kerja kerja induk itu adalah Madrasah Aliyah Swasta (MAS) Garut sebagai penyelenggara dan para guru MAS se-kecamatan Pasirwngi sebagai peserta kelompk kerja guru. Kemudian kelompok kerja intern adalah diadakan oleh MAS Al-Barakah sendiri dan khusus guru-guru Madrasah Aliayah Swasta Al-Barakah baik guru tetap maupun guru tidak tetap sebagai peserta Kelompok Kerja Guru (KKG). Adapun materimateri yang dibahas dalam Kelompok Kerja Guru ini meliputi tentang kurikulum, tentang evaluasi, tentang KKM (Kriteria Ketuntasan Minimal), dan lain-lain.

Oleh karena itu kelompok kerja guru sangat penting untuk dilaksanakan secara terus menerus karena melalui KKG ini di samping kekurangan seorang guru dapat ditutupi dengan meniru dan mempelajari kelebihan guru lain begitu pula sebaliknya juga menambah pengetahuan serta dapat menyatukan persepsi antara guru satu dengan guru yang lainnya dalam mewujudkan tujuan pembelajaran.

2. Workshop Pembelajaran

Dalam rangka peningkatan kompetensi guru, maka para guru Madrasah Aliayah Swasta Al-Barakah melaksanakan kegiatan workshop pembelajaran dengan tujuan untuk mengembangkan wawasan keilmuan Oleh karena itu melalai pelatihan-pelatihan tersebut kompetensi guru dapat dikembangkan dan ditingkatkan.

Sebagaimana yang diungkapkan oleh salah seorang informan mengatakan bahwa: dalam rangka untuk meningkatkan kompetensi/ kemampuan kita dalam kegiatan pendidikan dan pengajaran, maka melalui kegiatan workshop dapat membantu kami dalam mengelola pembelajaran.

\section{Seminar}

Kegiatan seminar merupakan salah satu kegiatan yang dapat meningkatkan kompetensi guru, adapun seminar yang dimaksudkan dapat meningatkan kompetensi guru adalah seminar tentang pendidikan, di samping itu mengikuti kegiatan seminarseminar yang lain yang relevan disiplin ilmunya. Dalam hal ini guru-guru MAS Al-Barakah senantiasa ikut berpartisifasi dalam mengikuti kegiatan seminar tersebut, sebagaimana hasil wawancara dengan salah seorang informan bahwa: mengenai kegiatan seminar ini terkadang kami dari guru MAS Al-Barakah mengikuti seminar yang diselenggarakan oleh instansi-instansi yang terkait. Dan kami mengikuti seminar, biasanya disurati oleh pihak penyelenggara yang diminta kesediaan untuk menjadi peserta seminar biasa pula 
mengikuti seminar tanpa ada surat permintaan oleh penyelenggara seminar akan tetapi kegiatan seminar tersebut, pesertanya berlaku untuk umum.

\section{Faktor Pendukung dan Penghambat}

\section{Faktor Pendukung}

Pelaksanaan manajemen pembelajaran dalam rangka untuk meningkatkan kompetensi guru pada umumnya dan kompetensi guru Madrasah Aliayah Swasta AlBarakah pada khususnya, dimana seorang guru harus memiliki kompetensi di bidangnya masing-masing. Begitu pula dengan adanya kebijakan pemerintah tentang guru mendapatkan tunjangan profesi kompetensinya, guru harus mengikuti uji kompetensi untuk mendapatkan sertifikasi sebagai syarat mendapat tunjangan profesi tersebut.

Dalam hal ini guru-guru MAS Al-Barakah sebagian sudah ada yang lulus uji kompetensi untuk mendapatkan sertifikasi, dipimpin oleh kepala sekolah yang memiliki komitmen tinggi, demokratis, luwes dalam melaksanakan tugasnya, memiliki tenaga pendidik yang rata-rata sarjana dan beberapa orang guru berkualifikasi magister, Peningkatan profesionalisme dan kompetensi guru telah dilakukan oleh Kepala Madrasah Aliayah Swasta Al-Barakah dengan mengikut sertakan guru-guru melakukan Kelompok Kerja Guru, seminar, workshop, tersedianya LCD proyektor di ruang kelas.

\section{Faktor Penghambat}

Minimnya ketersediaan buku-buku pendukung yang memudahkan guru dalam pelaksanaan proses pembelajaran, belum terpenuhinya secara maksimal fasilitas pembelajaran, keterbatasan ruangan, belum adanya ruangan laboratorium pembelajaran utamanya pada bidang studi IPA dan Bahasa, kurangnya media/alat peraga pembelajaran, dan lain-lain, masih minimnya skill guru yaitu belum semua guru menguasai alat teknologipembelajaran seperti menggunakan LCD, power point, dan lainlain, belum tersedianya perumahan guru, sementara tempat tinggal guru rata-rata berdomisili jauh dari Madrasah Aliayah Swasta Al-Barakah, guru selain menduduki jabatan fungsional, juga dibebani dengan tugas tambahan jabatan struktural, sehingga memiliki kesibukan yang cukup padat karena di samping tugasnya mengajar tugasnya, juga adanya tugas-tugas administrasi lainnya.

\section{B. Pembahasan}

Mazhab emprisme (Yunani en-di dalam; peira-suatu percobaan; sesuatu cara menemukan pengetahuan berdasarkan pengamatan dan percobaan).(Rusdiana 2018) Salah seorang diantaranya adalah Thomah Hobbes (1588-1679) yang mengatakan bahwa pengalaman merupakan permulaan segala pengenalan, pengalaman, intelektual tidak lain 
adalah semacam perhitungan yaitu penggabungan dari data-data inderawi. Jadi konsep Thomas Hobbes dalam aliran filsafat empirisme adalah aliran yang menyatakan bahwa semua pengetahuan berasal dari pengalaman manusia.

Pemikiran Thomas Hobbes berdasarka pada metode empiris-eksperimental. Maksudnya, ia ingin menarik kesimpulan suatu pengetahuan dari apa yang biasa diamati dan berdasarkan pengalaman nyata. Misalnya, ketika mengamati manusia, ia mengenyampingkan anggapan-anggapan metafisika tentang manusia, seperti moralitas, keabadian jiwa, dan kodrat sosial. Oleh karena itu, bagi Thomas Hobbes, pengetahuan yang benar adalah pengetahuan yang berdasarkan pengalaman dan observasi. Lantas bagaiman dengan perasaan-perasaan batiniyah ? Menurut Hobbes, dunia batiniyah dapat diobservasi melalui introspeksi. Yang diintrofeksi tentu saja adalah persaan-perasaan yang berdasarkan pada pengalaman-pengalaman. Tidak ada persaan yang muncul tanpa didasar i oleh pengalaman. Berdasarkan metode observasi dan introspeksi itulah, Thomas Hobbes menjabarkan pandangannya mengenai manusia dan masyarakat(Masykur 2013).

Dalam kajian filsafat tidak terlepas dari tiga cabang kajian filsafat yaitu ontologi, epistemologi dan aksiologi. Ontologi adalah cabang filsafat yang menghadirkan kembali pencarian atas upaya manusia untuk menemukan prinsip yang pertama (the first principle). Ontologi bukan semata-mata menyederhanakan segala sesuatu hingga sampai pada beberapa kesatuan akhir atau bahan yang paling mendasar, akan tetapi rindu pada suatu jawaban yang mendasar dan melingkupi segala sesuatu(Irawan 2019).

Landasan ontologis Manajemen Pendidikan Islam berada pada wilayah kajian antropo-fisik dan metafisik pada teori ontologi dualisme pengada manusia yaitu jasmani dan ruhani. Berarti secara ontologis, keseimbangan antara aspek jasmani dan ruhani dari sang pengelola peserta didik dan orang-orang yang dikelola (peserta didik) menjadi dasar pencapaian MPI (Irawan 2019). Manajemen Pembelajaran merupakan penggabungan dari kata manajemen dan Pembelajaran. Manajemen Pembelajaran merupakan upaya untuk memberikan layanan yang sebaik mungkin kepada peserta didik semenjak dalam proses penerimaan sampai saat peserta didik meninggalkan ruang pembelajaran (kelas) (Irawan 2019).

Maka dari itu semakin banyak pengalaman guru, maka akan banyak pula pengetahuan tentang berbagai metode dan cara penyampaian materi dan yang terpenting bagaimana cara mendidik dengan baik dan benar. Selain itu, pengetahuan guru harus disesuaikan dengan tujuan filsafat manajemen pendidikan islam dan ruang lingkup manajemen kurikulum pembelajarn yang harus dikelola oleh bagian kurikulum pembelajaran. Meskipun aliran filsafat empirisme memiliki beberapa keunggulan, akan tetapi ada empat kelemahan dari filsafat empirisme yaitu:(Ahmad 2006) indera terbatas, indera menipu, obyek yang menipu dan metode empiris tidak dapat diterapkan dalam semua ilmu.

Adapun tujuan manajemen pendidikan islam antara lain sebagai berikut :(Didin Kurniadin \& Imam Machali n.d.)

a) Terwujudnya suasana belajar dan proses pembelajaran yang aktif, inovatif, kreatif, efektif, dan menyenangkan (PAIKEM). b) Terciptanya peserta didik yang aktif mengembangkan potensi dirinya untuk memiliki kekuatan spiritual keagamaan, 
pengendalian diri, kepribadian, kecerdasan, akhlak mulia, serta keterampilan yang diperlukan dirinya, masyarakat, bangsa, dan negara. c) Terpenuhinya salah satu dari empat kompetensi tenaga pendidik dan kependidikan (tertunjangnya kompetensi professional sebagai pendidik dan tenaga kependidikan sebagai manager). d) Tercapainya tujuan pendidikan secara efektif dan efesien. e) Terbekalinya tenaga kependidikan dengan teori tentang proses dan tugas administrasi pendidikan (tertunjangnya profesi sebagai manajer atau konsultan manajemen pendidikan. f) Teratasinya masalah mutu pendidikan.

Tujuan manajemen pendidikan harus berorientasi pada tujuan peserta didik, yaitu pengembangan kepribadian dan kemampuan dasar peserta didik. Proses manajemen pendidikan harus dilandasi prinsip edukatif, yaitu bahwa proses manajemen tidak hanya dilandasi oleh prinsip mendidik. Sedangkan berdasarkan orientasinya, manajemen pendidikan berpusat pada peserta didik.

\section{KESIMPULAN}

Dari bahasan tentang filsafat empirisme dalam manajemen kesiswaan di atas, sangat jelas terlihat bahwa aliran Empirisme Pendidikan menghadirkan nuansa lain dari dunia pendidikan yang selama ini biasa diketahui. Empirisme pendidikan memposisikan peserta didik sebagai pihak yang sangat penting dan mesti dipahami dengan baik dan benar. Dengan pemahaman yang baik dan benar terhadap kebutuhan peserta didik, diharapkan agar peserta didik memiliki pengetahuan berdasarkan pengalamannya.

Dalam proses pelaksanaan manajemen KBM saat ini, pendidikan yang dimulai dari play group sampai dengan di tingkat pendidikan menengah juga telah menganut empirisme pendidikan. Walaupun demikian, tidak ada satu aliran pendidikan pun yang diterapkan secara sendiri-sendiri dalam sistem pendidikan. Selalu saja ada gabungan dari aliran-aliran pendidikan yang ada sehingga menghasilkan suatu sistem pendidikan yang baik dan dapat memenuhi standar. Berdasarkan hasil penelitian ini, maka dapat dikemukakan beberapa kesimpulan sebagai berikut: penerapan manajemen empirisme dalam pembelajaran untuk meningkatkan kompetensi guru di MAS Al-Barakah ditilik dari empat fungsi-fungsi proses manajemen POAC (planning, organizing, asctuating dan controlling), belum dilaksanakan secara maksimal fungsi manajemen tersebut yaitu baik pada proses perencanaan, pengorganisasian, pelaksanaan, maupun evaluasi. Bentukbentuk peningkatan kompetensi guru di Madrasah Aliyah Swasta Al-Barakah adalah Kelompok Kerja Guru (KKG), Workshop, dan seminar.

Faktor pendukung dan penghambat penerapan manajemen pembelajaran untuk meningkatkan kompetensi guru di MAS Al-Barakah adalah lembaga ini dipimpin oleh seorang kepala sekolah yang demokratis, luwes, memiliki tenaga pendidik rata-rata berkualifikasi Sarjana dan satu orang guru berkualifikasi Magister, peningkatan profesionalisme dan kompetensi guru yang telah dilakukan oleh Kepala MAS AL-Barakah dengan mengikutsertakan guru-guru melakukan KKG, seminar, workshop/pelatihan, dan sebagainya. 
Di samping memiliki faktor pendukung, namun terdapat pula factor penghambat yaitu masih minimnya ketersediaan buku-buku pendukung, belum terpenuhinya secara maksimal fasilitas pembelajaran, masih minimnya skill guru, belum tersedianya perumahan guru, dan guru selain menduduki jabatan fungsional, juga dibebani dengan tugas-tugas lainnya.

\section{DAFTAR PUSTAKA}

Abdul Majid. 2008. Perencanaan Pembelajaran:Mengembangkan Standar Kompetensi Guru. Bandung: PT Rosda Karya,.

Ahmad, Tafsir. 2006. Filsafat Ilmu. Bandung: Remaja Rosdakarya.

Didin Kurniadin \& Imam Machali. n.d. Manajemen Pendidikan Konsep \& Prinsip Pengelolaan Pendidikan.

Irawan. 2019. Filsafat Manajemen Pendidikan Islam. Bandung: PT Remaja Rosdakarya. Masykur, Arif Rahman. 2013. Buku Pintar Sejarah Filsafat Barat. Jogjakarta: IRCiSoD. Puspitasari, Ratna. n.d. “KONTRIBUSI EMPIRISME TERHADAP PENDIDIKAN ILMU PENGETAHUAN SOSIAL." Jurnal Edueksos Vol I No 1.

Rasmi. 2010. "Manajemen Mutu Pendidikan."

Rusdiana, A. 2018. Filsafat Ilmu. Bandung: Tresna Bhakti Press.

Suwardi. 2007. Manajemen: Mencipta Guru Kreatif Dan Berkompotensi,. Salatiga: STAIN Salatiga Press.

Widoyoko, S. Eko Putro. 2009. Evaluasi Program Pembelajaran: Panduan Praktis Bagi Pendidik Dan Calon Pendidik. Yogyakarta: Pustaka Pelajar.

Rasmi, Manajemen Mutu Pembelajaran di STAIN Sultan Qaimuddin Kendari, Tesis UIN Sunan Kalijaga Yogyakarta, (2010),. Selengkapnya dapat juga dilihat dalam H. Ramayulis, IlmuPendidian Islam, Jakarta: Kalam Mulia, 2008.

Sulistyorini, Manajemen Pendidikan Islam Konsep, Strategi dan Aplikasi,Yogyakarta: Teras, 2009. 